Cahiers $d u$ MONDE RUSSE

\title{
Cahiers du monde russe
}

Russie - Empire russe - Union soviétique et États indépendants

$47 / 4 \mid 2006$

Varia

\section{Olaf Mertelsmann, Der stalinistische Umbau in Estland}

\section{David Feest}

\section{OpenEdition}

\section{Journals}

Electronic version

URL: https://journals.openedition.org/monderusse/6807

DOI: $10.4000 /$ monderusse. 6807

ISSN: $1777-5388$

\section{Publisher}

Éditions de l'EHESS

\section{Printed version}

Date of publication: 30 December 2006

Number of pages: $940-943$

ISBN: 978-2-7132-2098-2

ISSN: $1252-6576$

\section{Electronic reference}

David Feest, "Olaf Mertelsmann, Der stalinistische Umbau in Estland", Cahiers du monde russe [Online], 47/4 | 2006, Online since 03 July 2009, connection on 02 September 2022. URL: http://

journals.openedition.org/monderusse/6807; DOI: https://doi.org/10.4000/monderusse.6807

This text was automatically generated on 2 September 2022

All rights reserved 


\title{
Olaf Mertelsmann, Der stalinistische Umbau in Estland
}

\author{
David Feest
}

\section{REFERENCES}

Olaf MERTELSMANN, Der stalinistische Umbau in Estland. Von der Markt- zur

Kommandowirtschaft. Hamburg : Kovač, 2006, 303 p. (Hamburger Beiträge zur

Geschichte des östlichen Europa, 14)

1 The first economic plan for the Estonian Socialist Republic was issued in December 1940 under chaotic circumstances. A local organization of the planning agency Gosplan had just been founded and was working under the direction of a trustworthy party worker from Moscow. Nevertheless, most of its workers had little experience in Soviet style economy, work was done in a hodgepodge way, economical institutions were repeatedly reorganized and the state officials had a hard time understanding the Russian instructions from Moscow. In a letter to the Estonian Council of Peoples Commissars even the most important word -industry- had to be translated into Estonian in a handwritten margin note. A vivid description of the first Soviet year at the beginning of Olaf Mertelsmann's book already makes clear, that although the Baltic States were incorporated into the economic system of the Soviet Union, it took some time for them to adjust to the standards already established in the old Soviet republics. According to the author, the party leadership followed the aim of sovietization with a trial and error method. The special situation of the newly acquired territories that were reoccupied in 1944 , and the resulting differences to the rest of the union, make the book an interesting read.

However, Mertelsmann's focus is broader. Although the book is merely a preliminary study, he aims at giving an overview of the entire process of sovietization of the Estonian economy: population growth, agriculture, the standard of living and even the often neglected sphere of service. Drawing on writings by P.Gregory and others 
Mertelsmann prefers the terms " command economy » or « managed economy » to the term " planned economy » common in German, since the means to actually implement a central plan was limited. Showing how economy really worked, the author inevitably repeats observations that have been made with respect to the old republics of the Soviet Union. For instance, it is hardly surprising that union-wide phenomena like deficits, the autarchy of regions and enterprises, or practices like shadow economy, illegal methods of procurement or personalised power relations and a great deal of improvisation can also be found in the post-war industry in Estonia. The same goes for the factors leading to a low standard of living, especially the negligible wholesale prices for agricultural products, the prohibition of market relations and the focus on heavy industry. Although by including memories and other non-statistical material in the description of the economical development Mertelsmann's book gains a certain local flavour (and also a great amount of readability), it is not always clear, what was specific about the Estonian case.

3 This is not to say, that the author has nothing new to offer. Especially the careful evaluation and correction of the often dubious statistical material is not to be underestimated. Of course, historians have previously had more than a hunch that the statistical material, proving for instance a breathtaking pace of industrialization in Estonia after the war, could not be taken at face value. But Mertelsmann pins down in detail, how fictional plan-fulfillment, hidden inflation and fixed prices as well as outright falsifications could be the basis of such statistics.

4 In addition to the above, Mertelsmann takes a firm stand in some of the most controversial issues concerning the industrialization in the Baltic States. For instance, on the grounds of the internal balance of trade from 1944 to 1948, that shows heavy investments in the small republic, he rejects the notion of Estonia having been a victim of some kind of colonial exploitation and sees it rather as a victim of failed economic policies. Also, he argues that the mass immigration of Russian speaking workers into Estonia was not planned by the state, but happened spontaneously as a result of the famine in Russia. The central power, Mertelsmann states, would not have been able to effectively implement such a policy.

5 This last point is an important one, but it also shows that an exclusively socioeconomic argumentation can have its shortcomings. After all, the state might nevertheless have been interested in this development, as the widespread propaganda about the leading role of Russian culture in the forties suggests as well as the privileges that were granted for the immigrants.

6 This danger of a reductionistic account also appears with regard to other topics. For instance, Mertelsmann convincingly shows, that besides imposing a non effective economic system, the Communist Party made some grievously wrong decisions concerning the direction of the Estonian economy. Thus, the allocation of vast sums into the north-eastern Estonian oil shale industry proved to be a misinvestment in the long run, due to the inferior material. But the author makes no attempts to explain these decisions as a part of an ideology of heavy industry, that sometimes seems to have gone beyond rational considerations.

7 Mertelmann's general tendency to factor out the political dimension seems especially inappropriate, when he tries to explain the collectivization of agriculture in Estonia exclusively as an attempt to exploit the countryside and pump the money into industrialization. In doing so, the author ignores not only the great amount of research 
that denies this effect and stresses the political motives for collectivization, but also doesn't take into account the new situation after the war, when the Soviet leaders knew from experience what the economical outcome of collectivization would be like. If the Bolsheviks thought in the late 1920, that profit could be made through collectivization a claim, that can been questioned - they had no reason to still believe this after the war. Why they repeated the collectivization drive anyway is not a trivial question, and by presupposing simple economical reasons Mertelsmann avoids going deeper into the subject.

Also, a couple of small shortcomings are surprising. The fact that he never explicitly mentions the fourth Five-Year Plan (1946-1950) may seem inadequate in a book on command economy. A more serious omission is the virtual absence of the currency reform of December 1947 that is mentioned only once briefly. In fact, it was more than just a means of fighting inflation - in regard to the whole Soviet Union it has been said, that it «clearly bore confiscational character $»^{1}$. In the newly occupied territories it furthermore functioned as a politically and economically essential step to eliminate the remains of the free market. In the same vain, Mertelsmann doesn't pay much attention to the unification of small enterprises and collective farms to large scale unions in 1950. These were in fact an important step in destroying the old structures that had survived even in the kolkhoz system. For many, they appeared to be a " second collectivization ».

In the last chapter, the author engages in a little bit of counterfactual historical speculation, making clear once more, that the very collectivization, in addition to low prices for agricultural products, as well as the misallocation of capital into the unproductive oil shale industry, stand out as the main reasons for the bad economic performance of Soviet Estonia in the post-war years. These errors, Mertelsmann maintains, could have been avoided even within a Soviet framework, whereas as an independent country Estonia would even have had the chance to perform - as the author puts in a strangely Soviet-like formula - a « leap into the first league of the developed industrial nations. » (p. 269)

In spite of the above criticism the overall evaluation of the book clearly has to be a positive one. It is the first post-Soviet attempt to provide an overview over the economic sovietization in Estonia. And in contrast to many other overviews it is mainly based on a wide range of archival sources. It is true, the statistical work inevitably suffers from a certain amount of incredibility of the sources and can sometimes be done only by means of small case studies. However, Mertelsmann uses the quantitative material in a cautious way and juxtaposes it with a great amount of narrative statements that give insight into the daily practices of the Soviet economy. The outcome is a very readable and useful account of the Soviet command economy in Estonia.

\section{NOTES}

1. O. Chlevnjuk, «Die sowjetische Wirtschaftspolitik im Spätstalinismus und die Affäre 'Gosplan' », Osteuropa, 9, 2000, p. 1031-1047, here: p. 1035. 